\title{
Phylogenetic and pathotype analysis of Escherichia coli swine isolates from Southern Brazil ${ }^{1}$
}

\author{
Lilian Kolling Girardini' ${ }^{2}$, Franciele M. Siqueira ${ }^{3}$, Carina C. Krewer ${ }^{2}$, Cristina C. \\ Krewer ${ }^{4}$, Mateus M. da Costa ${ }^{4}$ and Agueda C. de Vargas ${ }^{2^{*}}$
}

\begin{abstract}
Girardini L.K., Siqueira F.M., Krewer C.C., Krewer C.C., Costa M.M. \& Vargas A.C. 2012. Phylogenetic and pathotype analysis of Escherichia coli swine isolates from Southern Brazil. Pesquisa Veterinária Brasileira 32(5):374-378. Departamento de Medicina Veterinária Preventiva, Universidade Federal de Santa Maria, Camobi, Santa Maria, RS 97105-900, Brazil. E-mail: agueda.vargas@gmail.com

The current study evaluated the presence of virulence factors by a multiplex PCR technique and then phylogenetically classified the studied strains into groups A, B1, B2 and D, according to Clermont et al. (2000), in 152 intestinal and extraintestinal swine isolates of Escherichia coli. Seventy seven isolates tested were positive for virulence factors. Phylogenetic characterization placed 21 samples into group A, 65 into B1, 19 into B2 and 47 into D. Fourteen urine samples were classified as uropathogenic E. coli (UPEC), nine were both UPEC and enterotoxigenic E. coli (ETEC) and four were ETEC only. The most common phylogenetic classifications were B1 and D groups. Of the analyzed fecal samples, 25 were classified as ETEC. Phylogenetically, the group of higher occurrence was B1, followed by B2, $A$ and D. For the small intestine samples, 20 were classified as ETEC. Phylogenetic analysis found groups B1 and A to be the most commons in these samples. Six isolated tissue samples were classified as ETEC and most of them were designated as group D by phylogenetic classification. The phylogenetic analysis could be employed in veterinary laboratories in the $E$. coli isolates screening, including the possibility of vaccine strain selection and epidemiological searches.
\end{abstract}

INDEX TERMS: Escherichia coli, E. coli typification, phylogeny, uropathogenic E. coli, enterotoxigenic E. coli.

RESUMO.- [Análise filogenética e de patotipos de Escherichia coli isoladas de suínos no Sul do Brazil.] 0 presente estudo teve por objetivo avaliar a presença de diferentes fatores de virulência em 152 isolados de Escherichia coli intestinais e extra-intestinais provenientes de suínos pela técnica de PCR multiplex e classificá-los nos grupos filogenéticos A, B1, B2 e D, de acordo com Clermont et al. (2000).

\footnotetext{
${ }^{1}$ Received on September 12, 2011.

Accepted for publication on December 15, 2011.

${ }^{2}$ Departamento de Medicina Veterinária Preventiva, Universidade Federal de Santa Maria (UFSM), Av. Roraima, Camobi Santa Maria, RS 97105900, Brazil. *Corresponding author: agueda.vargas@gmail.com

${ }^{3}$ Programa de Pós-Graduação em Bioquímica, Universidade Federal do Rio Grande do Sul (UFRGS), Av. Ramiro Barcelos, Porto Alegre, RS 91501970, Brazil.

${ }^{4}$ Laboratório de Microbiologia e Imunologia Animal, Colegiado de Zootecnia, Fundação Universidade Federal do Vale do São Francisco, Petrolina, PE 89820-000, Brazil.
}

Setenta e sete isolados foram positivos para pelo menos um fator de virulência. Através da caracterização filogenética, 21 isolados foram caracterizados como pertencentes ao grupo A, 65 ao grupo B1, 19 ao grupo B2 e 47 isolados ao grupo D. Quatorze isolados de urina foram caracterizados como E. coli uropatogênica (UPEC); nove apresentaram fatores de UPEC e E. coli enterotoxigênica (ETEC) simultaneamente e quatro foram classificados como ETEC. Na classificação filogenética, os isolados provenientes de amostras de urina classificaram-se principalmente nos grupos D e B1. Das amostras de fezes analisadas, 25 demonstraram fatores de virulência característicos do patotipo ETEC. Filogeneticamente, o grupo de maior ocorrência foi o B1 seguido de B2, A e D. Em relação às cepas isoladas de intestino delgado, 20 foram caracterizadas como ETEC. Pela filogenia, 23 isolados classificaram-se nos grupos A ou B1. Seis isolados de tecidos foram qualificados como ETEC e a maioria deles foram designados como pertencentes ao gru- 
po D, pela classificação filogenética. A análise filogenética pode ser empregada em laboratórios de diagnóstico veterinário como um screening para isolados de E. coli, incluindo a possibilidade de seleção de cepas vacinais e levantamentos epidemiológicos.

TERMOS DE INDEXAÇÃO: Escherichia coli, tipificação de E. coli, filogenia, E. coli uropatogênica, E. coli enterotoxigênica.

\section{INTRODUCTION}

The bacterium Escherichia coli is a normal inhabitant of human and animal intestine. Some E. coli strains can cause a wide variety of intestinal and extraintestinal diseases, such as diarrhea, urinary tract infections and septicemia (Orskov \& Orskov 1992). Diseases incidence is associated with many factors, which includes animal characteristics, poor nutrition, inapropriated handling (Brito et al. 1999), and the pathogenicity characteristics of the involved strain (Gyles \& Fairbrother 2010).

E. coli isolates are characterized into different pathotypes according to the presence of specific virulence factors. The main pathotypes in swine diseases are enterotoxigenic E. coli (ETEC), characterized by the presence of the toxins STa, STb and LT and F4, F5, F6, F18 or F41 fimbria; enteropathogenic E. coli (EPEC), which carries the eae gene; Shiga toxigenic or Verotoxigenic E. coli (STEC or VTEC), characterized by the presence of factors such as $\mathrm{F} 18 \mathrm{a} / \mathrm{b}$ fimbria and Stx2 toxin, and finally uropathogenic E. coli (UPEC), which carries at least one of the following genes: cnf, hly, bfp, eae, sfa, pap, iha and usp (Brito et al. 1999, Campos et al. 2008, Afset et al. 2008).

Diagnosis of illness is carried out by phenotypic tests for microorganism identification; however, these tests are limited due to the evaluation subjectivity and to the individual variations of each strain. Serotyping can also be used to classify the species, but specific anti-sera are not readily available for serotype identification. Therefore, genotyping of $E$. coli strains based on the presence or absence of the virulence factors by polymerase chain reaction (PCR) has been widely used to characterize pathotypes (Beier et al. 2005). Some studies have attempted to identify the evolutionary origin of extraintestinal $E$. coli by using pathogenic marker analysis to classify the isolates into different phylogenetic groups (Johnson et al. 2001; Luna et al. 2010; Moulin-Schouleur et al. 2007). Phylogenetic analyses have shown that strains of this agent can be placed into four main groups: A, B1, B2 and D. The virulent strains usually belong to group B2 and, less commonly, to group D. Conversely, the commensal isolates belong to groups A and B1 (Clermont et al. 2000).

In Brazil, there are a limited number of studies involving the molecular characterization of $E$. coli strains of swine origin (Brito et al. 1999, Costa et al. 2006, Costa et al. 2008, Costa et al. 2010) as well as its classification into phylogenetic groups. The aims of the current study were the characterization of swine E. coli isolates by multiplex PCR (mPCR) and to classify these isolates into phylogenetic groups.

\section{MATERIALS AND METHODS}

A total of 152 isolates of Echerichia coli were used in the present study: Seventy gilt urine samples of animals from piglets with reproductive and urinary problems (however the status of each animal was unknown), 35 fecal samples of piglets presenting problems of diarrhea, 35 samples of intestinal content from piglets with no clinical signs of disease and 12 tissue samples ( 6 livers, 3 lungs, 2 brains and 1 gall bladder) of piglets with clinical signs of diarrhea and dehydration. The samples were collected from three different swine breeding farms from Rio Grande do Sul State and 15 different swine breeding farms from Santa Catarina State, Brazil. The samples were previously identified by biochemical tests (Quinn et al. 1994) and kept lyophilized until bacterial DNA extraction by thermal extraction method. Isolated colonies on ovine blood agar $5 \%$ were diluted in sterile deionized water and boiled for 7 minutes, and then, centrifuged at 13,000 rpm for 5 minutes. The DNA was obtained from the supernatant and was used for different PCR methods.

The E. coli samples were genotyped using two MPCR assays to detect fimbria and toxins by amplifying the following gene encoding for regions: STa (158 bp), STb (113 bp), LT (272 bp), STx (758 bp), F4 (499 bp), F5 (230 bp), F6 (520 bp), F18 (313 bp) and F41 (613 bp), for the intestinal, fecal and tissue samples; and cnf (543 bp), hly (1117 bp), bfp (326 bp), eae (368 bp), pap (328 bp), iha (827 bp), sfa (410 bp), cnf (543 bp) and usp (440 bp) for the urinary isolates, as previously described (Brito et al. 2004, Costa et al. 2008, Blanco et al. 1996, Blanco et al. 1997). The mPCR was carried out with reactions of $25 \mu \mathrm{l}$ containing 100ng of DNA, 30 pmol of each primer, $1 \mathrm{X}$ Taq buffer $(10 \mathrm{mM}$ Tris, $50 \mathrm{mM} \mathrm{KCl}, 2.5$ $\mathrm{mM} \mathrm{MgCl}_{2}$ ), $200 \mu \mathrm{M}$ each deoxyribonucleotide triphosphate and $1 \mathrm{U}$ of Taq DNA polymerase. Termocycling conditions were: 35 cycles of 45 seconds at $94^{\circ} \mathrm{C}, 1$ minute at $55^{\circ} \mathrm{C}, 45$ seconds at $72^{\circ} \mathrm{C}$ and a final extension of 7 minutes at $72^{\circ} \mathrm{C}$.

E. coli isolates were classified by phylogenetic PCR as previously described (Clermont et al. 2000). The PCR reaction mix was the same as described above. The amplification of genes chuA (279 bp) and yjaA (211 bp) and TspE4.C2 (152 bp) DNA fragment was obtained with a denaturation step for 5 minutes at $94^{\circ} \mathrm{C}$, followed by 30 cycles of 30 seconds at $94^{\circ} \mathrm{C}, 30$ seconds at $55^{\circ} \mathrm{C}$ and 30 seconds at $72^{\circ} \mathrm{C}$ and a final extension of 7 minutes at $72^{\circ} \mathrm{C}$.

Aliquots of $10 \mu \mathrm{l}$ amplification products were subjected to electrophoresis for 45 minutes at $100 \mathrm{~V}$ in $1.5 \%$ agarose gel stained with ethidium bromide. DNA fragments were compared with a 50 bp DNA ladder. Gel was visualized and photographed under ultraviolet light. Group B2 includes isolates $c h u A+/ y j a A+$; group D, chuA+/yjaA-; group B1, chuA-/TSPE4.C2+ and group A, chuA-/ TSPE4.C2-. Analysis was performed to compare the results than genotyping mPCR and phylogenetic PCR of E. coli strains using the chi-square test. The level of significance was established at a $p$ value of 0.05 . The statistical tests were performed using the SAS package (SAS Institute, 2000).

\section{RESULTS AND DISCUSSION}

The phylogenetic classification performed in the current study demonstrated that the most representative groups observed among swine Escherichia coli isolates were B1 and D, while other studies with human isolates showed groups A and B2 as the most prevalents (Picard et al. 1991). Strains of human origin are expected to be in the B2 E. coli group. Animal's strains are more resistant to antibiotics, less virulent and classified in non B2 groups (Sabaté et al. 2008). These differences may also be correlated to geographical variations, individual characteristics of the hosts and 
due to the insufficiency of studies involving phylogenetic analyses of swine samples and also the lack of standard reference strains of natural populations (Escherichia coli Reference Collection).

The urine's phylogenetic classification, small intestine, fecal and tissue isolates compared to the presence or absence of virulence factors by MPCR is described in Table 1. From 152 E. coli isolates tested by mPCR, 51\% (77) were positive for at least one of the virulence factors, while phylogenetic characterization found $42 \%$ (65) in of isolates in group B1, 31\% (47) in D 14\% (21) in A and 13\% (19) in group B2.

Table 1. Phylogenetic classification of urine, feces, small intestine and tissue Escherichia coli isolates from swine in comparison with the presence or absence of virulence factors by multiplex polymerase chain reaction

\begin{tabular}{|c|c|c|c|c|c|c|c|c|c|}
\hline \multirow[t]{2}{*}{$\begin{array}{l}\text { Phylogenetic } \\
\text { group }\end{array}$} & \multicolumn{2}{|c|}{$\begin{array}{l}\text { Urine } \\
(\mathrm{N}=70)\end{array}$} & \multicolumn{2}{|c|}{$\begin{array}{c}\text { Feces } \\
(\mathrm{N}=35)\end{array}$} & \multicolumn{2}{|c|}{$\begin{array}{c}\text { Small } \\
\text { intestine } \\
(\mathrm{N}=35)\end{array}$} & \multicolumn{2}{|c|}{$\begin{array}{l}\text { Tissue } \\
(\mathrm{N}=12)\end{array}$} & \multirow[t]{2}{*}{$\begin{array}{c}\text { Percentage of } \\
\text { agreement }\end{array}$} \\
\hline & $t^{a}$ & - & + & - & + & - & + & - & \\
\hline $\mathrm{A}^{*}$ & 0 & 8 & 3 & 2 & 2 & 3 & 0 & 3 & $76.00 \%$ \\
\hline $\mathrm{B} 1 *$ & 9 & 14 & 13 & 8 & 10 & 8 & 1 & 2 & $49.23 \%$ \\
\hline $\mathrm{B} 2^{* *}$ & 5 & 2 & 6 & 0 & 5 & 1 & 0 & 0 & $84.20 \%$ \\
\hline $\mathrm{D}^{* *}$ & 12 & 20 & 3 & 0 & 3 & 3 & 5 & 1 & 48.93 \\
\hline Total & 26 & 44 & 25 & 10 & 20 & 15 & 6 & 6 & \\
\hline
\end{tabular}

a + Presence of virulence factors; - absence of virulence factors; $*$ Classified as Commensal or ${ }^{* *}$ virulent group by phylogenetic PCR (Clermont et al. 2000).
The majority of urine isolates $(62.8 \%)$ were negative for virulence factors when tested by mPCR, which is consistent with previous findings (Costa et al. 2008). The remaining $37.1 \%(26 / 70)$ were positive for one or more virulence factors, $20 \%$ of these $(14 / 70)$ were classified as UPEC, $12.8 \%$ (9/70) as both UPEC and ETEC and 5.8\% (4/70) as ETEC (Fig.1A). In the phylogenetic grouping, 55.8\% (39/70) were classified into groups B2 and D, of which $45.8 \%(32 / 70)$ were classified as group D. The $44.2 \%$ (31/70) remaining ones were classified as either group A or B1 (23/70). From the 31 samples phylogenetically classified as commensals, $29 \%(9 / 31)$ contained one or more virulence factors using mPCR, while out of the 39 samples considered pathogenic, $53.8 \%(21 / 39)$ did not show any virulence gene $(P<0.05)$.

Seventy one per cent $(25 / 35)$ of fecal samples analyzed, contained one or more ETEC virulence factors (Fig.1B). In the phylogenetic analysis, the most abundant group was B1, followed by B2, A and D, respectively. Studies carried out with $E$. coli from fecal samples of several domestic animal species found pylogroups A, B1 and D were prevalent, but in swine no virulence genes were associated (Unno et al. 2009). The same author report that major phylogroup found in feces were A group. The same results were described for swine feces in Brazil by Carlos et al. (2010) that suggest B1 group as the most environmental resistant group of $E$. coli.

Seventy four per cent $(26 / 35)$ of samples were classified as commensals, of which $38.4 \%$ (10/26) did not show
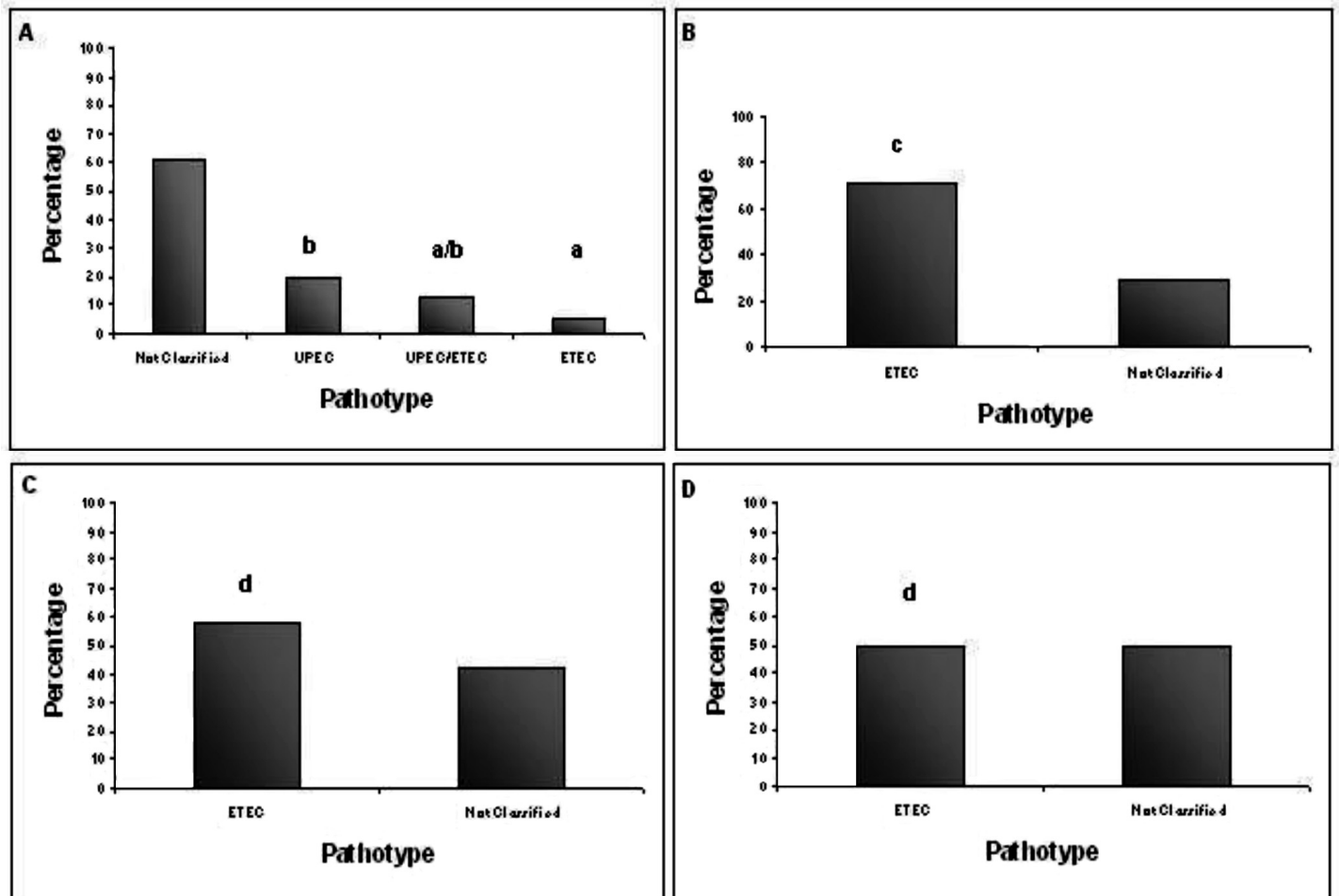

Fig.1. Pathotype characterization and virulence factors of urine (A), feces (B), small intestine (C), and tissue (D) E. coli isolates from swine. a = presence of at least one virulence factors (STa, STb, STx, LT); b = presence of at least one virulence factors (iha, pap, hly, sfa, usp); $a / b=$ presence of at least one of both virulence factors characteristic of enterotoxigenic E. coli (ETEC) and uropathogenic $E$. coli (UPEC) pathotypes; c = presence of at least one virulence factors (F4, F5, F6, F41, STa, STb, STx, LT); d = presence of at least one virulence factors (F4, F5, F6, STa, STb, LT); Not Classified = negative for virulence factors tested by multiplex polymerase chain reaction. 
any virulence factor by mPCR (Table 1 ). Accordly, Chapman et al. (2006) in swine, the most commensal strains belonged to groups A and B1, with occasional predominance of phylogroup A (Schierack et al. 2007). In another study from commensal samples the phylogenetic groups A and B1 were prevalent, but ampicillin treatment led to a shift in the composition of the fecal E. coli population, with selection for ampicillin-resistant strains belonging to phylogroup A (Bibbal et al. 2009). In contrast with the most of the studies, group B2 clones were most frequently isolated, followed by group A, D, and B1 clones isolates from E. coli microflora of wild boars (Schierack et al. 2009).

The analysis of small intestine samples, characterized $57.2 \%$ (20/35) as ETEC (Fig. 1C). In the phylogenetic analysis, $65.6 \%(23 / 35)$ of the isolates were classified in groups A or B1. The same results were described by Picard et al. (1991) and Chapman et al. (2006), which can reflect a preference of specific virulence factor coded by plasmids from certain genetic groups (Turner et al. 2006). A total of $34.4 \%$ were placed into groups B2 $(6 / 35)$ and D $(6 / 35)$. The phylogenetic group B2 is not common in intestinal samples from domestic swine (Chapman et al. 2006) and boars (Schierack et al. 2009). From the samples classified in pathogenic phylogenetic groups, $66.6 \%(8 / 12)$ were found to be positive for virulence factors by MPCR, which was also found in $52.2 \%(12 / 23)$ of the samples that were considered commensals. Using mPCR, none of the fecal or small intestine isolates was classified as EPEC or STEC pathotypes in the current study. These results support previous findings of $E$. coli pathogenesis in isolates from Brazil (Costa et al. 2006).

Fifty per cent of tissue isolates $(6 / 12)$ were classified as ETEC (Fig.1D) and fifty per cent (6/12) of the samples were classified into group D, followed by group A and B1, each one containing $25 \%$ of the samples $(3 / 12)$. These data differ from previous ones which observed that human pathogenic extraintestinal strains were typically classified in group B2 (Gyles \& Fairbrother 2010). One (16.6\%) commensal isolate showed virulence factors $(P<0.05)$. Accordingly to Picard et al. (1999), B1 and D phylogenetic group can be highly virulent for animal models, but B2 phylogenetic group strains are clearly the most virulent strains, which are genetic divergence of strains among the $E$. coli species.

Some urinary samples were classified as UPEC, while others were positive for UPEC and ETEC virulence factors, which is also consistent with previous findings that demonstrated the presence of these two pathotypes in swine samples (Brito et al. 2004). Urinary strains demonstrating only ETEC factors were also observed. This data reinforces the fact that urinary tract infections in swine can be ascendant of gastrointestinal tract infections (Brito et al. 2004). Phylogenetic analysis demonstrated that the urinary samples classified according to the pathogenic groups were grouped primarily into group $\mathrm{D}$, different from previous studies which observed that human pathogenic extraintestinal strains were typically classified in group B2 (Gyles \& Fairbrother 2010). According to Sabaté et al. (2008), animal E. coli isolates are classified in non B2 groups. In the present study, a higher number of urine samples were classified in commensal groups, most of them in group B1, while previous findings showed nonpathogenic strains typically assembled into group A (Clermont et al. 2000). Commensal $E$. coli of animals and humans demonstrate diversity in the distribution of phylogenetic groups of different populations (Picard et al. 1999).

Fifty two percent of the commensal isolates presented virulence genes by mPCR. This was also determined in $29 \%$ of the urine samples. Clinical and commensal E. coli strains are diverse in their genetic traits. Commensal E. coli are considered silent autochthones bacteria that can sometimes harbor virulence genes. In the current case, lack of the correct gene association may be related to no disease development. The presence of virulence genes is not equivalent to its expression. Genes that are turned to facilitate infections had their expression dependent on environmental and immunologic conditions (Chapman et al. 2006).

The remaining 21 fecal and small intestine samples were classified into groups B2 and D. Thirty three per cent $(4 / 12)$ of the pathogenic isolates were negative for all of the tested virulence genes. However, the absence of these genes does not mean that the strains are not virulent, since the pathogenesis of $E$. coli can be evaluated by some other less studied genes (Geyid et al. 1996) that were not tested in the present study. The combination of virulence genes cannot fully define each pathotype, but may contribute to typify disease syndrome (Chapman et al. 2006). Under different selection pressures clones that possess nonadvantagenous virulence genes could be eliminated and replaced with less frequent ones. These changes may be associated with the use of $E$. coli in immunization programs of sows to produce protective antibodies in the colostrums (Chapman et al. 2006).

The direct search of virulent determinants by mPCR is essential for the correct evaluation of $E$. coli pathogenesis. This search is limited, however, because only the main known factors were investigated, which most likely does not reflect reality (Picard et al. 1991). Results of the current study diverged from studies using human strains (Picard et al. 1991), but confirms previous studies on the subject of $E$. coli swine and others animal species isolates (Chapman et al. 2006, Sabaté et al. 2008). No absolute definition of virulence in $E$. coli is possible considering differences in species pathogenesis. Studies have suggested that $E$. coli isolates may have a multi-ancestral origin, one from pathogenic lineage and another from non-pathogenic lineage that possibly evolved by the horizontal acquisition of virulent genes (Silveira et al. 2002).

As $\mathrm{mPCR}$ is a technique that analyzes specific virulence factors, the phylogenic technique can be used for grouping swine pathogenic isolates while no essential virulence genes would be determined. With this, we propose the use of the phylogenetic analysis technique in veterinary laboratory diagnostic in screening of potential virulent $E$. coli isolates.

\section{REFERENCES}

Afset J.E., Anderssen E., Bruant G., Harel J., Wieler L. \& Bergh K. 2008. Phylogenetic backgrounds and virulence profiles of atypical entero- 
pathogenic Escherichia coli strains from a case-control study using multilocus sequence typing and DNA microarray analysis. J. Clin. Microbiol. 46:2280-2290.

Beier R.C., Bischoff K.M., Ziprin R.L., Poole T.L. \& Nisbet D.J. 2005. Chlorhexidine susceptibility, virulence factors, and antibiotic resistance of betahemolytic Escherichia coli isolated from neonatal swine with diarrhea. Bull. Environ. Contam. Toxicol. 75:835-844.

Bibbal D., Dupouy V., Prère M.F., Toutain P.L. \& Bousquet-Mélou A. 2009. Relatedness of Escherichia coli Strains with Different Susceptibility Phenotypes Isolated from Swine Feces during Ampicillin Treatment. Appl. Environ. Microbiol. 75:2999-3006.

Blanco J.E., Blanco M., Blanco J., Mora A., Balaguer L., Mourino M., Juarez A. \& Jansen W.H. 1996. 0 serogroups, biotypes, and eae genes in Escherichia coli strains isolated from diarrheic and healthy rabbits. J. Clin. Microbiol. 34:3101-3107.

Blanco M., Blanco J.E., Alonso M.P., Mora A., Balsalobre C., Munoa F., Juárez A. \& Blanco J. 1997. Detection of pap, sfa and $a f a$ adhesin-encoding operons in uropathogenic Escherichia coli strains: relationship with expression of adhesins and production of toxins. Res. Microbiol. 148:745755.

Brito B.G., Leite D.S., Linhares R.E. \& Vidotto M.C. 1999. Virulence-associated factors of uropathogenic Escherichia coli - UPEC strains for pigs. Vet. Microbiol. 65:123-132.

Brito B.G., Vidotto M.C., Berbel M.M. \& Tagliari K.C. 2004. Virulence factors of uropathogenic Escherichia coli: UPEC strains for pigs. Ciência Rural 34:645-652.

Campos T.A., Lago J.C., Nakazato G., Stehling E.G., Brocchi M., Castro A.F.P. \& Silveira W.D. 2008. Occurrence of virulence-related sequences and phylogenetic analysis of commensal and pathogenic avian Escherichia coli strains (APEC). Pesq. Vet. Bras. 28:533-540.

Carlos C., Pires M.M., Stoppe N.C., Hachich E.M., Sato M.I., Gomes T.A.T., Amaral L.A. \& Ottoboni L.M.M. 2010. Escherichia coli phylogenetic group determination and its application in the identification of the major animal source of fecal contamination. BMC Microbiol. 10:161.

Chapman T.A., Wu X.Y., Barchia I., Bettelheim K.A., Driesen S., Trott D., Wilson M. \& Chin J.J.C. 2006. Comparison of virulence gene profiles of Escherichia coli strains isolated from healthy and diarrheic swine. Appl. Environ. Microbiol. 72:4782-4795.

Clermont O., Bonacorsi S. \& Bingen E. 2000. Rapid and simple setermination of the Escherichia coli phylogenetic group. Appl. Environ. Microbiol. 66:4555-4558.

Costa M.M., Silva M.S., Spricigo D.A., Witt N.M., Marchioro S.B., Kolling L. \& Vargas A.C. 2006. Epidemiology, molecular characterization and resistance to antimicrobials of Escherichia coli isolated from South-Brazilian pig herds. Pesq. Vet. Bras. 26:5-8.

Costa M.M., Dresher G., Maboni F., Weber S., Botton S.A., Vainstein M.H., Schrank I.S. \& Vargas A.C. 2008. Virulence factors and antimicrobial resistance of Escherichia coli isolated from urinary tract of swine in southern of Brazil. Braz. J. Microbiol. 39:741-743.

Costa M.M., Drescher G., Maboni F., Weber S.S., Schrank A., Vainstein M.H., Schrank I.S. \& Vargas A.C. 2010. Virulence factors, antimicrobial resistance, and plasmid content of Escherichia coli isolated in swine commercial farms. Arq. Bras. Med. Vet. Zootec. 62:30-36.
Geyid A., Fletcher J., Gashe B.A. \& Ljungh A. 1996. Invasion of tissue culture cells by diarrheagenic strains of Escherichia coli which lack the enteroinvasive inv gene. FEMS Immunol. Med. Microbiol. 14:15-24.

Gyles C.L. \& Fairbrother J.M. 2010. Escherichia coli, p. 267-308. In: Gyles C.L., Prescott J.F., Songer J.G. \& Thoen C.O. (Eds), Pathogenesis of Bacterial Infections in Animals. $4^{\text {th }}$ ed. Iowa: Wiley-Blackwell, Ames, Iowa.

Johnson J.R., Delavar I.P., Kuskowski M. \& Stell A.L. 2001. Phylogenetic distribution of extraintestinal virulence associated traits in Escherichia coli. J. Infect. Dis. 183:78-88.

Luna G.M., Vignaroli C., Rinaldi C., Pusceddu A., Nicoletti L., Gabellini M., Danovaro R. \& Biavasco F. 2010. Extraintestinal Escherichia coli Carrying Virulence Genes in Coastal Marine Sediments. Appl. Environ. Microbiol. 76: 5659-5668

Moulin-Schouleur M., Répérant M., Laurent S., Brée A., Mignon-Grasteau S., Germon P., Rasschaert D. \& Schouler C. 2007. Extraintestinal pathogenic Escherichia coli strains of avian and human origin: Link between phylogenetic relationships and common virulence patterns. JCM 45:3366-3376.

Orskov F. \& Orskov I. 1992. Escherichia coli serotyping and disease in man and animals. Can. J. Microbiol. 38:699-704.

Picard B., Picard-Pasquiet N., Krishnamoorthy R. \& Goullet P. 1991. Characterization of highly virulent Escherichia coli strains by ribosomal DNA restriction fragment length polymorphism. FEMS Microbiol. Lett. 66:183-188.

Picard B., Garcia J.S., Gouriou S., Duriez P., Brahimi N., Bingen E., Elion J. \& Denamur E. 1999. The link between phylogeny and virulence in Escherichia coli extraintestinal infection. Infect. Immun. 67:546-553.

Quinn P.J., Carter M.E., Markey B. \& Carter G.R. 1994. Clinical Veterinary Microbiology. Wolfe, London, UK.

SAS Institute. 2000. SAS/STAT User's Guide, Version 8. Cary.1383p.

Sabaté M., Prats G., Moreno E., Ballesté E., Blanch A.R. \& Andreu A. 2008. Virulence and antimicrobial resistance profiles among Escherichia coli strains isolated from human and animal wastewater. Res. Microbiol. 159:288-293.

Schierack P.N., Walk K., Reiter K.D. \& Wieler L.H. 2007. Composition of intestinal Enterobacteriaceae populations of healthy domestic pigs. Microbiology 153:3830-3837.

Schierack P., Römer A., Jores J., Kaspar H., Guenther S., Filter M., Eichberg J. \& Wieler L.H. 2009. Isolation and characterization of intestinal Escherichia coli clones from wild boars in Germany. Appl. Environ. Microbiol. 75:695-702.

Silveira W.D., Ferreira A., Brocchi M., Hollanda L.M., Castro A.F.P., Yamada A.T. \& Lancellotti M. 2002. Biological characteristics and pathogenicity of avian Escherichia coli strains. Vet. Microbiol. 85:47-53.

Turner S.M., Chaudhuri R.R., Jiang Z.D., DuPont H., Gyles C., Penn C.W., Pallen M.J. \& Henderson I.R. 2006. Phylogenetic comparisons reveal multiple acquisitions of the toxin genes by enterotoxigenic Escherichia coli strains of different evolutionary lineages. J. Clin. Microbiol. 44:4528-4536.

Unno T., Han D., Jang J., Lee S., Ko G.P., Choi H.Y., Kim J.H., Sadowsky M.J. \& Hur H.G. 2009. Absence of Escherichia coli Phylogenetic Group B2 Strains in Humans and Domesticated Animals from Jeonnam Province, Republic of Korea. Appl. Environ. Microbiol. 75:5659-5666. 